\title{
The International DOVETAIL Program
}

Robin D. Muench ${ }^{1}$

\section{Germany}


2 The "Deep Ocean Ventilation Through Antarctic Intermediate Layers" (DOVETAIL) 3 program is an international field and modeling study of the dense deep and bottom waters of the 4northwestern Weddell Sea. A primary program goal has been to estimate the volume transport and 5pathways of these waters, long considered to be a major source of Antarctic Bottom Water, as they 6escape from the Weddell Sea over and through the South Scotia Ridge into the Scotia Sea. 7Corollary goals are to assess modification of the stratification during passage through the narrow, 8steep-sided and irregular channels that transect the Ridge. The program has evolved, since its start 9in 1997 as a primarily process-oriented project, into a multiyear observational study of the 10northwestern Weddell Sea-southern Scotia Sea including the Weddell-Scotia Confluence region. 11An additional program goal has, therefore, become the estimation of interannual variability in the 12physical system. This volume contains a collection of papers that present recent field and model13derived results from the DOVETAIL program. 


\section{Background}

2 Dense water produced in the Weddell Sea is a significant, if quantitatively uncertain, 3component of the global inventory of Antarctic Bottom Water (AABW) (Broecker et al., 1998; 4Orsi et al., 1999; Hellmer and Beckmann, 2001). Field programs over the last several decades 5have led to a consensus about how this dense water is produced. The two principalmodes of 6production are as follows. One process entails the addition of brine released during sea ice 7 formation to form a dense shelf-resident water mass calld high salinity shelf water (HSSW). The 8HSSW then mixes near the continental shelf break with Modified Warm Deep Water(MWDW), 9which is a mixture of Warm Deep Water (WDW) and Winter Water (WW) (Foster and Carmack, 101976; Foster et al., 1988). A second process invokes the additional step of cooling and freshening 11of shelf water beneath ice shelves followed by downslope flow at the shelf break and mixing with 12ambient waters (Foldvik et al., 1985). The addition of fresh water through glacial melt provides a 13characteristic isotope signal to the deep water formed through the second process, allowing the 14relative importance of both processes to be assessed (Weppernig et al., 1996).

15 Regardless of the production mechanism, dense water in the Weddell Sea is predominantly 16a result of ocean/atmosphere or ocean/ice-shelf heat and salt exchanges that occur over the broad 17southern and western continental shelves. Once formed, the dense waters flow down the adjoining 18continental slopes as density currents. These dense "plumes" interleave with ambient deep water 19masses or form broad, sheet-like bottom layers that can be up to several hundred meters thick and 20in places extend over most of the continental slope (Gordon et al., 1993; Gordon, 1998). The dense 21 sheet of bottom water flows northward along the western rim of the Weddell Sea, adjacent to the 22Antarctic Peninsula, and is enhanced en route by additional sources along the Peninsula, such as 23from the Larsen Ice Shelf (Muench and Gordon, 1995; Fahrbach et al., 1995). 
1 As these dense flows reach the northeastern tip of the Peninsula, slope currents deeper than 2about $2000 \mathrm{~m}$ are primarily constrained by bottom topography to continue eastward along the 3southern flank of the South Scotia Ridge (Figure 1). Subject to seasonal and interannual 4variations, the plume splits, with part following a cyclonic path around Powell Basin and the 5remainder proceeding directly toward the South Orkney Plateau (Gordon et al., 2001). Shallow 6 fractions can exit into the Scotia Sea from northern Powell Basin, with deeper fractions entering 7the Scotia Sea through passages in the South Scotia Ridge east of the South Orkney Islands. The 8deepest, densest components are prevented by the topography from exiting the Weddell Basin 9across the Ridge (Orsi et al., 1993; 1999).

10 Additional dense water can form during winter on the shelves adjacent to the northern tip 11of the Antarctic Peninsula (Whitworth et al., 1994; Gordon et al., 2000). There, local winds and 12topography can cause divergence in the sea ice cover, creating open water areas that are subject to 13high rates of sea ice formation. A significant fraction of these modified shelf waters flows 14northward past the tip of the Peninsula and contributes to ventilation of the Bransfield Strait basins 15(Gordon et al., 2000).

16 Topography is a major factor in determining the pathways through which dense water 17 formed in the Weddell Sea can escape into the Scotia Sea. The constraint applies throughout the 18water column: the weak stratification in this region implies that the currents include a significant 19barotropic component that is steered along $f / H$ contours due to vorticity conservation. Several 20processes can overcome this topographic steering to allow property and mass transport across 21sloping bathymetry. These processes include isopycnal mixing (intrusions at water mass 22boundaries, and mesoscale instabilities in the circulation), channelization by cross-slope canyons, 23buoyancy modification by ocean-atmosphere and ocean-ice interactions, and diapycnal (quasi- 
1 vertical) mixing that transports properties from one density range to another. These processes are 2not well documented in the Weddell-Scotia region.

\section{The DOVETAIL Program}

5 The international "Deep Ocean Ventilation Through Antarctic Intermediate Layers" 6(DOVETAIL) program was organized in response to our uncertainty concerning the northward 7volume transport of Weddell Sea deep and bottom waters over the South Scotia Ridge and the 8pathways for this flow. DOVETAIL combines a multi-year field data collection program with 9numerical modeling efforts. The basic hypothesis driving the scientific investigations holds that 10the South Scotia Ridge, a topographically complex, zonally-trending ridge cut by several deep 11passages, exerts a strong control over the magnitudes and pathways of the deep water transports. 12Consequently, the program has focussed on the northwestern Weddell Sea and southern Scotia 13Sea, which includes the Weddell-Scotia Confluence region (Patterson and Sievers, 1980), and the 14passages through the South Scotia Ridge (Figure 1).

15 Some early DOVETAIL field results have been published (Gordon et al., 2000; 2001;

16Fahrbach et al., 2001). The collection of papers contained in this issue presents additional field 17results along with conclusions based on numerical modeling studies.

18

\section{The Collection}

20 The following collection is comprised of eight contributions. Three of these present 21 conclusions that are based primarily on results from numerical models. Five present analyses 22derived primarily from field observations, one supplemented by the results of an inverse box 23model study. Two of the model-based studies utilize large-scale ocean circulation models of 
1different complexity and resolution and discuss results over a broad region centered on the South 2Scotia Ridge. These studies emphasize flow pathways and attempt to better quantify the transport 3of Weddell Sea waters across the South Scotia Ridge. Seasonal circulation and upper ocean 4variability is also assessed. A third model-based study utilizes a vertical model to assess upper 5ocean water mass modifications due to interactions with a sea ice cover. The field-based studies, 6like the model studies, address DOVETAL objectives by attempting to better quantify the 7pathways and exports of deep and bottom waters in the northwestern Weddell Sea. The ongoing 8 field activities already have provided an extensive database which, together with future field work, 9will be used in an assessment of interannual to decadal variability. Deep and bottom water 10transports are shown to vary with the regional sea ice cover extent and with the magnitude of shelf 11water formation farther south. Simple analytical models for diapycnal mixing are applied to field 12data and yield new insight into processes that can modify the water masses during their northward 13transit through the South Scotia Ridge region. The energy for mixing results in part from the 14interaction between tidal currents and the steep local topography.

15 We believe that these works significantly enhance our understanding of processes that 16influence the production of dense water in the Antarctic Zone of the Southern Ocean and its 17spreading into the world ocean. However, they raise additional questions which we continue to 18address by expanding the international DOVETAIL field program beyond 2002. The initial 19intensive, process-oriented program thrust has been replaced by a long-term, lower level effort. An 20ongoing U.S. program of deep moored observations in the region south of South Orkney Island is 21providing measurements of seasonal and interannual variability in the currents, temperature and 22salinity characteristics of the deep waters there. An ongoing annual sequence of summer cruises to 23the region as part of a Brazilian-German collaboration provides a more detailed glimpse of the 
1regional, full-depth temperature and salinity fields and allows a continued observation of 2interannual changes. Data analysis and modeling efforts will be performed in parallel with the 3field work.

4

\section{Acknowledgments}

6 The several components of the international DOVETAIL program have been supported by 7agencies of Brazil, Germany, Spain, the United Kingdom, and the United States. Specific support 8is acknowledged in each of the collected papers. Compilation of this collection has been made 9possible through the support of the U.S. National Science Foundation and of the Alfred-Wegener10Institute for Polar and Marine Research. We are much indebted to the many reviewers, who were 11willing to work against tight deadlines, for the collection. A.L. Gordon provided useful input on 12an early version of this overview. The international Antarctic Zone (iAnZone) group, an affiliated 13program of the Scientific Council on Ocean Research (SCOR), played a crucial role in the 14planning and compilation of this collection. This is Earth \& Space Research Contribution number $15 X X X$

16

\section{References}

18Broecker, W.S., Peacock, S.L., Walker, S., Weiss, R., Fahıbach, E., Schröder, M., Mikolajewicz, 19 U., Heinze, C., Key, R., Peng, T.-H., Rubin, S., 1998. How much deep water is

20 formed in the Southern Ocean? Journal of Geophysical Research 103, 15883-15843.

22Foster, T.D., Carmack, E.C., 1976. Frontal zone mixing and Antarctic Bottom Water 23 formation in the southern Weddell Sea. Deep-Sea Research 23, 301-317. 
1 Foster, T.D., Foldvik, A., Middleton, J.H., 1988. Mixing and bottom water formation in 2the

3 shelf break region of the southern Weddell Sea. Deep-Sea Research 34, 1771-1794.

4Fahrbach, E., Rohardt, G., Scheele, N., Schröder, M., Strass, V., Wisotzki, A., 1995.

5 Formation and discharge of deep and bottom water in the northwestern Weddell Sea.

6 Journal of Marine Research 53, 515-538.

7Fahrbach, E., Harms, S., Rohardt, G., Schröder, M., Woodgate, R., 2001. Flow of bottom

8 water in the northwestern Weddell Sea. Journal of Geophysical Research 106, 2761-

92778.

10Foldvik, A., Gammelsrød, T., Tørresen, T., 1985. Circulation and water masses on the

11 southern Weddell Sea shelf. In: Jacobs, S.S.(Ed.), Oceanology of the Antarctic

12 Continental Shelf, Antarctic Research Series 43. American Geophysical Union,

13 Washington D.C., pp. 5-20.

14Gordon, A.L., Huber, B., Hellmer, H.H., Ffield, A., 1993. Deep and bottom water of the

15 Weddell Sea’s western rim. Science 262, 95-97.

16 Gordon, A.L., 1998. Western Weddell Sea thermohaline stratification. In: Jacobs, S.S., 17Weiss,

18 R.F. (Eds.), Ocean, Ice and Atmosphere: Interactions at the Antarctic Continental

19 Margin, Antarctic Research Series 75. American Geophysical Union, Washington D.C.,

20 pp. $215-240$.

21Gordon, A.L., Mensch, M., Dong, Z., Smethie, W.M., Jr., Bettencourt, J. de, 2000. Deep

22 and bottom waters of the Bransfield Strait eastern and central basins. Journal of

23 Geophysical Research 105, 11337-11346. 
1Gordon, A.L., Visbeck, M., Huber, B., 2001. Export of Weddell Sea deep and bottom water. 2 Journal of Geophysical Research 106, 9005-9018.

3Hellmer, H.H., Beckmann, A., 2001. The Southern Ocean: A ventilation contributor with

4 multiple sources. Geophysical Research Letters 28, 2927-2930.

5Muench, R.D., Gordon, A.L., 1995. Circulation and transport of water along the western

6 Weddell Sea margin. Journal of Geophysical Research 100, 18503-18515.

7Orsi, A.H., Nowlin, W.D., Jr., Whitworth, T., III, 1993. On the circulation and stratification

8 of the Weddell Gyre. Deep-Sea Research Part I 40, 169-203.

9Orsi, A.H., Johnson, G.C., Bullister, J.L., 1999. Circulation, mixing, and production of

10 Antarctic Bottom Water. Progress in Oceanography 43, 55-109.

11Patterson, S.L., Sievers, H.A., 1980. The Weddell-Scotia Confluence. Journal of Physical 12 Oceanography $10,1584-1610$.

13Weppernig, R., Schlosser, P., Khatiwala, S., Fairbanks, R.G., 1996. Isotope data from Ice 14 Station Weddell: Implications for deep water formation in the Weddell Sea. Journal of 15 Geophysical Research 101, 25723-25739.

16Whitworth, T., III, Nowlin, W.D., Jr., Locarnini, R.A., Smith, S.G., 1994. Weddell Sea shelf 17 water in the Bransfield Strait and Weddell-Scotia Confluence. Deep-Sea Research 41, $18 \quad 629-641$.

19

\section{Figure Legend}

21Figure 1. Bathymetric details and geographical placenames within and surrounding the 22DOVETAIL study region. 


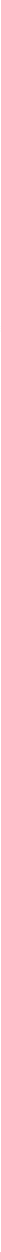

